\title{
ANALISIS FAKTOR KESULITAN BELAJAR SISWA PADA MATA PELAJARAN BIOLOGI DI KELAS X IPA SMA NEGERI 4 KISARAN
}

\author{
Helentina ${ }^{1)^{*}}$, Ahmad Shafwan, S. Pulungan $^{2)}$, Arlina Sinaga ${ }^{3)}$ \\ ${ }^{1,2}$ Program Studi Pendidikan Biologi, FMIPA, Universitas Negeri Medan, Medan Jl. Willem Iskandar Psr. V \\ Medan Estate, Medan, Indonesia, 20221 \\ ${ }^{3}$ SMA Negeri 4 Kisaran, Jalan Pondok Indah, 20256 \\ *E-mail : helentinab@gmail.com
}

\begin{abstract}
ABSTRAK
Penelitian ini bertujuan untuk mengetahui kesulitan belajar siswa pada mata pelajaran biologi. Jenis penelitian ini adalah penelitian deskriftif kuantitatif. Sampel digunakan secara Total Sampling yang meliputi, 34 orang siswa kelas X IPA-1, 34 orang siswa kelas X IPA -2, 33 orang siswa kelas X IPA-3, 33 orang siswa kelas X IPA-4, dan 31 orang siswa kelas X IPA-5. Instrumen penelitian lembar angket sebanyak 40 pertanyaan. Hasil penelitian menunjukkan bahwa siswa mengalami kesulitan belajar pada setiap aspek. Faktor internal yang menjadi penyebab kesulitan belajar siswa adalah faktor intelegensi, perhatian siswa, motivasi, minat, kesehatan. Sedangkan faktor eksternal yang menyebabkan siswa mengalami kesulitan belajar adalah alat pelajaran, lingkungan sekolah, media, metode/strategi mengajar guru, orangtua.
\end{abstract}

Kata kunci : kesulitan belajar

\section{ABSTRACT}

The objective of this study is to know difficulties rate of students on biology subjects. This study is quantitative descriptive research. The sample was taken in total sampling involved comprising 34 students as Grade X IPA-1, another 34 students Grade X IPA-2, still 33 students grade X IPA-3, also 33 students Grade X IPA-4, and 31 students Grade X IPA-5. The instrument of provided questionnaire paper with 40 questions. The result indicated that students got difficulties to study on each. The internal factor as causes go difficulties of students in studying known as factor of intelligence, attention of students, motivation, interest, health as well as. While, external factor cause the students got difficulties in studying seemly tool for learning, environmental, media, method/ strategic done by teacher, and parents.

Keywords: learning difficulties

\section{PENDAHULUAN}

Proses pencerdasan bangsa bisa terlaksana jika dilakukan melalui jalur pendidikan, yang bertujuan untuk meningkatkan kualitas sumber daya manusia sebagai faktor yang sangat menentukan dalam keberhasilan pembangunan. Keberhasilan atau kegagalan proses pendidikan sangat bergantung pada faktor siswa, instrumen pembelajaran, instrumen penunjang, dan penggerak proses pendidikan.

Dalam kegiatan pembelajaran di sekolah, para guru dihadapkan dengan sejumlah karakteristik siswa yang beranekaragam. Ada siswa yang dapat menempuh kegiatan belajarnya secara lancar dan berhasil tanpa mengalami kesulitan, namun disisi lain tidak sedikit pula siswa yang dalam belajarnya mengalami berbagai kesulitan (Sunarto, 2008).

Pembelajaran adalah suatu kegiatan yang bernilai edukatif dan mewarnai interaksi yang terjadi antara guru dan siswa. Dalam proses pembelajaran tidak menutup kemungkinan siswa mengalami kesulitan dalam belajar. Kesulitan belajar merupakan suatu keadaan dimana siswa tidak dapat belajar sebagaimana mestinya proses pembelajaran yang baik, hal ini disebabkan oleh hambatan atau gangguan tertentu dalam proses pembelajaran sehingga siswa tidak dapat mencapai hasil belajar yang diharapkan (Dimyanti, 2013). Anak berkesulitan belajar dapat dilihat dari prestasi belajar yang rendah, usaha dalam belajar tidaksebanding dengan hasil yang dicapainya, sikap acuh tak acuh dalam mengikuti pelajaran, dan sikap kurang wajar lainya.

Kesulitan belajar yaitu keadaan siswa yang mengalami penurunan kinerja akademik atau prestasi belajar. Kesulitan belajar pada anak atau sering disebut disorders sangat erat kaitannya dengan pencapaian hasil akademik dan juga aktivitas seharihari. Anak yang mengalami kesulitan belajar adalah anak yang memiliki gangguan satu atau lebih dari proses dasar yang mencakup pemahaman penggunaan bahasa lisan atau tulisan, gangguan 
tersebut dapat menampakkan diri dalam bentuk kemampuan yang tidak sempurna dalam mendengar, berfikir, berbicara, membaca, mengeja, dan menghitung (Syah, 2010).

Penelitian ini dilaksanakan di SMA Negeri 4 Kisaran karena dari hasil observasi didapat bahwa kurangnya minat dalam belajar biologi, hal ini dapat disebabkan oleh faktor dari dalam diri siswa itu sendiri sehingga siswa berpendapat bahwa mata pelajaran biologi itu merupakan mata pelajaran yang membosankan dan sulit dipahami. Faktor sekolah juga berpengaruh, seperti penggunaan model dan metode dalam pembelajaran, fasilitas sekolah yang kurang dimanfaatkan yaitu laboratorium dan perpustakaan yang kurang dimanfaatkan. Faktor keluarga, seperti bimbingan orangtua yang kurang, dan kurangnya motivasi guru untuk meningkatkan minar belajar biologi siswa.

Dari hasil observasi yang dilakukan di SMA Negeri 4 Kisaran bahwa rata-rata hasil ulangan pada mata pelajaran biologi peserta didik rendah. Siswa yang tidak dapat mencapai kriteria ketuntasan minimum (KKM) 75 yang telah ditetapkan oleh sekolah. Hal ini membuktikan bahwa hasil ulangan merekasebanyak $75 \%$ yang mengalami kegagalan pada mata pelajaran biologi tesebut. Rendahnya hasil ulangan siswa mengindikasikan bahwa terdapat kesulitan belajar yang dialami peserta didik di kelas $X$ IPA dalam mempelajari pelajaran biologi sehingga nilai yang diperoleh masih rendah.

Jika dilihat dari faktor internal (segi jasmaniah) siswa dalam mengikuti proses pembelajaran biologi sudah baik. Siswa belajar dengan kesehatan yang baik, tidak terdapat siswa yang cacat mental. Namun, terdapat faktor internal dari segi psikologi yang kurang baik. Hal ini tampak ketika melakukan observasi, terdapat siswa yang tidak membawa buku pegangan biologi dan tidak membawa buku catatan pada saat pembelajaran biologi. Selain itu juga banyak siswa yang berbincangbincang, tidak memperhatikan guru mengajar, bahkan mengganggu teman saat pelajaran sedang berlangsung sehingga keadaan kelas tidak kondusif. Keadaan ini tentu akan menyebabkan siswa tidak mampu menyerap materi pelajaran dengan baik sehingga mengakibatkan rendahnya hasil belajar siswa. Dapat dilihat juga bahwa tidak ada siswa yang mengikuti kegiatan olimpiade biologi. Hal ini yang menunjukkan kurangnya perhatian siswa pada mata pelajaran biologi.

Tujuan penelitian ini adalah Mengetahui faktorfaktor penyebab kesulitan belajar siswa dalam mempelajari mata pelajaran biologi di Kelas X IPA SMA Negeri 4 Tahun Pembelajaran 2016/2017 dan menganalisis penyebab kesulitan belajar siswa di Kelas $X$ IPA SMA Negeri 4 Kisaran Tahun Pembelajaran 2016/2017.

\section{METODE PENELITIAN}

Penelitian ini telah dilaksanakan di SMA Negeri 4 Kisaran beralamat di jalan Pondok Indah, Kecamatan Kisaran Barat pada bulan Februari sampai Mei tahun 2017.

Jenis penelitian ini adalah deskriptif kuantitatif. Populasi penelitian adalah seluruh siswa kelas X IPA SMA Negeri 4 Kisaran Tahun Pembelajaran 2016/2017. Sampel penelitian ini diambil secara total sampling yaitu seluruh siswa kelas X IPA SMA Negeri 4 Kisaran.

Untuk memperoleh data yang dibutuhkan, maka instrumen yang digunakan dalam penelitian ini dengan memberikan angket kepada siswa yang tidak mencampai kriteria ketuntasan maksimum. Angket yang digunakan adalah angket tertutup yang terdiri dari 35 pernyataan. Masing-masing pernyataan disediakan pilihan yang menjadi alternatif jawaban dan perhitungan skor menggunakan skala linkert dengan ketentuan sebagai berikut:

1. Untuk pernyataan dengan kriteria positif: $1=$ tidak pernah, 2=kadang-kadang 3= sering, 4=selalu.

2. Untuk pernyataan dengan kriteria negatif: $1=$ selalu, 2= sering, 3= kadang-kadang, 4=tidak pernah.

Tabel 2. Kisi-Kisi Angket Analisis Faktor Kesulitan Belajar Siswa 


\begin{tabular}{|c|c|c|c|c|}
\hline No. & Indikator & Deskriptor & No.Item Soal & Jumlah \\
\hline \multicolumn{5}{|c|}{ Faktor Internal } \\
\hline \multirow[t]{3}{*}{1.} & Kesehatan & $\begin{array}{l}\text { - Siswa dapat mendengarkan penjelasan dan informasi } \\
\text { daari guru dengan jelas. }\end{array}$ & 1 & 3 \\
\hline & & $\begin{array}{l}\text { - Siswa dapat melihat dengan jelas pelajaran } \\
\text { yang ditulis di papan tulis. }\end{array}$ & 2 & \\
\hline & & $\begin{array}{l}\text { Siswa kurang tidur, banyak aktivitas sehingga } \\
\text { tidak maksimal dalam mengikuti pelajaran. }\end{array}$ & 3 & \\
\hline \multirow[t]{4}{*}{2.} & Perhatian & $\begin{array}{l}\text { - Siswa sulit memusatkan perhatian ketika KBM biologi } \\
\text { berlangsung. }\end{array}$ & 4 & 4 \\
\hline & siswa & $\begin{array}{l}\text { - Siswa banyak kegiatan dan sulit berkonsentrasi terhadap } \\
\text { pelajaran. }\end{array}$ & 5 & \\
\hline & & $\begin{array}{l}\text { - Siswa memiliki masalah, sehingga sulit berkonsentrasi } \\
\text { terhadap pelajaran. }\end{array}$ & 6 & \\
\hline & & $\begin{array}{l}\text { - Mendapatkan nilai yang baik dalam mata pelajaran } \\
\text { biologi, dibutuhkan perhatian yang sunguh-sungguh. }\end{array}$ & 7 & \\
\hline \multirow[t]{6}{*}{3.} & Intelegensi & $\begin{array}{l}\text { - Belajar biologi dituntut pemahaman dan konsentrasi } \\
\text { penuh. }\end{array}$ & 8 & 6 \\
\hline & & $\begin{array}{l}\text { - Siswa mengeluarkan pendapat saat KBM biologi } \\
\text { berlangsung. }\end{array}$ & 9 & \\
\hline & & $\begin{array}{l}\text { - Siswa menjawab pertanyaan yang diberikan guru dan } \\
\text { teman pada saat diskusi berlangsung. }\end{array}$ & 10 & \\
\hline & & - Mata pelajaran biologi sulit dipelajari. & 11 & \\
\hline & & $\begin{array}{l}\text { - Siswa dengan cepat memahami konsep-konsep biologi } \\
\text { saat KBM berlangsung. }\end{array}$ & 12 & \\
\hline & & - Mengingat materi yang sudah disampaikan oleh guru. & 13 & \\
\hline \multirow[t]{4}{*}{4.} & Minat & $\begin{array}{l}\text { - Siswa aktif mengerjakan tugas biologi dan menyerahkan } \\
\text { tugas tepat waktu. }\end{array}$ & 14 & 4 \\
\hline & & - Siswa menyukai pelajaran biologi. & 15 & \\
\hline & & $\begin{array}{l}\text { - Siswa membaca buku-buku biologi lain selain buku } \\
\text { pegangan dari sekolah. }\end{array}$ & 16 & \\
\hline & & $\begin{array}{l}\text { - Memanfaatkan waktu luang mengulang kembali } \\
\text { pelajaran yang sudah berlalu. }\end{array}$ & 17 & \\
\hline \multirow[t]{3}{*}{5.} & Motivasi & $\begin{array}{l}\text { - Tertarik untuk menlanjutkan materi pelajaran biologi } \\
\text { ditingkat yang lebih tinggi. }\end{array}$ & 18 & 3 \\
\hline & & $\begin{array}{l}\text { - Merasa puas dengan nilai diperoleh pada mata pelajaran } \\
\text { biologi. }\end{array}$ & 19 & \\
\hline & & - Mengubah cara belajar ketika mendapat nilai rendah & 20 & \\
\hline \multicolumn{5}{|c|}{ - Faktor Eksternal } \\
\hline \multirow[t]{6}{*}{6.} & Metode/Stra & $\begin{array}{l}\text { - Guru kurang menguasai bahan sehingga materi yang } \\
\text { diajarkan kurang jelas. }\end{array}$ & 21 & 6 \\
\hline & & - Kesdisplinan guru dalam memasukikelas. & 22 & \\
\hline & Mengajar & - Guru menggunakan metode mengajar yang berariasi. & 23 & \\
\hline & Guru & - Sikap guru terhadap siswa saat mengajar. & 24 & \\
\hline & Gura & - Guru memberikan simulasi kepada siswa. & 25 & \\
\hline & & $\begin{array}{l}\text { - Guru mengadakan remedial kepada siswa apabila nilai } \\
\text { ujian rendah. }\end{array}$ & 26 & \\
\hline \multirow[t]{2}{*}{7.} & Alat & - Perpustakan memiliki banyak buku mengenai biologi. & 27 & 2 \\
\hline & & - Tersedianya laboratorium di sekolah. & 28 & \\
\hline
\end{tabular}




\begin{tabular}{|c|c|c|c|c|}
\hline & Pelajaran & & & \\
\hline \multirow[t]{3}{*}{8.} & Media & - Guru menggunakan media ITC untuk menjelaskan. & 29 & 3 \\
\hline & & $\begin{array}{l}\text { - Memanfaatkan acara televisi yang menyajikan tentang } \\
\text { materi biologi. }\end{array}$ & 30 & \\
\hline & & $\begin{array}{l}\text { - Siswa memiliki fasilitas pendukung dalam mempelajari } \\
\text { pelajaran biologi. }\end{array}$ & 31 & \\
\hline \multirow[t]{6}{*}{9.} & Orang Tua & - Mendukung untuk memiliki buku biologi dari sumber lain. & 32 & 6 \\
\hline & & - Menyuruh untuk belajar secara teratur. & 33 & \\
\hline & & $\begin{array}{l}\text { - Mendapat pujian/hadiah dari orang tua jika mendapat } \\
\text { nilai baik. }\end{array}$ & 34 & \\
\hline & & $\begin{array}{l}\text { - Orangtua membimbing dan membantu dalam } \\
\text { mengerjakan tugas biologi. }\end{array}$ & 35 & \\
\hline & & - Orangtua anda menyediakan bimbingan belajar. & 36 & \\
\hline & & $\begin{array}{l}\text { - Orangtua anda menanyakkan nilai yang anda dapatkan } \\
\text { sewaktu ujian. }\end{array}$ & 37 & \\
\hline \multirow[t]{4}{*}{10.} & Lingkungan & - Kondisi fisik sekolah yang memadai untu kebutuhan & 38 & 3 \\
\hline & Sekolah & Kolonalanna & & \\
\hline & & $\begin{array}{l}\text { - Kelengkapan buku-buku yang menyangkut pelajaran } \\
\text { biologi di perpustakaan. }\end{array}$ & 39 & \\
\hline & & - Letak sekolah strategis dan jauh dari keramaian. & 40 & \\
\hline
\end{tabular}

Hasil angket dianalisis dengan cara mencari rata-rata skor angket siswa, jumlah total skor yang dicapai pada tiap indikator angket dengan rumus:

$\mathrm{P}=\frac{F}{N} \times 100 \%($ Sudijono, 2010)

Keterangan :

$\mathrm{P}=$ angka persentase

$\mathrm{F}=$ frekuensi yang sedang dicari persentasenya

$\mathrm{N}=$ Number of Cases ( jumlah frekuesi/ banyaknya individu)

Berdasarkan uraian di atas dapat disusun kriteria kesulitan siswa

\begin{tabular}{cc}
\hline Persentase Kesulitan & Kriteria \\
\hline $81-100 \%$ & Sangat berpengaruh \\
$61-80 \%$ & Berpengaruh \\
$41-60 \%$ & Cukup berpengaruh \\
$21-40 \%$ & Kurang berpengaruh \\
$0-20 \%$ & Sangat tidak berpengaruh \\
\hline
\end{tabular}

(Arikunto, 2013)

\section{HASIL PENELITIAN}

Setelah mengetahui tingkat kesulitan belajar siswa dalam mempelajari mata pelajaran biologi, maka diperoleh faktor penyebab siswa mengalami kesulitan belajar melalui angket. Dari angket yang telah diberikan kepada siswa, maka hasil dari angket tersebut dikelompokkan sesuai dengan indikator-indikator kesulitan belajar yang diukur dari faktor internal maupun eksternal. Berdasarkan Tabel 4.1. faktor kesulitan belajar siswa tertinggi terdapat pada indikator intelegensi, yaitu sebesar $71,01 \%$ yang berarti berpengaruh, dan faktor kesulitan belajar terendah yaitu indikator kesehatan sebesar 41,48\% yang berarti cukup berpengaruh. Pada faktor internal dilihat dari hasil penelitian, indikator kesehatan sebesar $41,48 \%$ yang berarti cukup berpengaruh, indikator perhatian siswa sebesar $65,04 \%$ yang berarti berpengaruh, indikator intelegensi sebesar 71,01\% yang berarti berpengaruh, indikaor minat sebesar $60,04 \%$ yang berarti berpengaruh dan indikator motivasi sebesar $61,29 \%$ yang berarti berpengaruh. 
Pada faktor eksternal dapat dilihat dari faktor sekolah, hasil penelitian dari faktor sekolah meliputi indikator metode/strategi mengajar guru sebesar 59,62\% yang berarti cukup berpengaruh, indikator alat pelajaran sebesar $70,64 \%$ yang berarti berpengaruh, indikator media sebesar $61,48 \%$ yang berarti berpengaruh, indikator orangtua sebesar $55,61 \%$ yang berarti cukup berpengaruh, dan indikator lingkungan sekolah sebesar 70,55\% yang berarti berpengaruh.

Setelah diketahui skor angket tiap indikator maka skor tersebut akan disesuaikan dengan kriteria hasil persentase angket menurut Arikunto (2010). Artinya akan diketahui skor angket tesebut sangat berpengaruh, berpengaruh, cukup berpengaruh, kurang berpengaruh, sangat tidak berpengaruh. Perhitungan analisis dapat dilihat pada tabel.

Tabel 2. Kategori Faktor Penyebab Kesulitan Belajar Siswa

\begin{tabular}{|c|c|c|c|c|c|c|}
\hline \multirow[t]{2}{*}{ No } & \multirow[t]{2}{*}{ Indikator } & \multirow{2}{*}{$\begin{array}{c}\text { Jumlah } \\
\text { Item }\end{array}$} & \multicolumn{2}{|c|}{ Jumlah Skor } & \multirow[t]{2}{*}{$\%$} & \multirow[t]{2}{*}{ Kategori } \\
\hline & & & Ideal & Nyata & & \\
\hline 1. & Kesehatan & 3 & 1620 & 672 & 41,48 & Cukup Berpengaruh \\
\hline 2. & $\begin{array}{l}\text { Perhatian } \\
\text { Siswa }\end{array}$ & 4 & 2160 & 1405 & 65,04 & Berpengaruh \\
\hline 3. & Intelegensi & 6 & 3240 & 2301 & 71,01 & Berpengaruh \\
\hline 4. & Minat & 4 & 2160 & 1297 & 60,04 & Berpengaruh \\
\hline 5. & Motivasi & 3 & 1620 & 993 & 61,29 & Berpengaruh \\
\hline 6. & $\begin{array}{l}\text { Metode/ } \\
\text { Strategi } \\
\text { Mengajar } \\
\text { Guru }\end{array}$ & 6 & 3240 & 1932 & 59,62 & Cukup Berpengaruh \\
\hline 7. & Alat Pelajaran & 2 & 1080 & 763 & 70,64 & Berpengaruh \\
\hline 8. & Media & 3 & 1620 & 996 & 61,48 & Berpengaruh \\
\hline 9. & Orangtua & 6 & 3240 & 1802 & 55,61 & Cukup Berpengaruh \\
\hline 10. & $\begin{array}{l}\text { Lingkungan } \\
\text { Sekolah }\end{array}$ & 3 & 1620 & 1143 & 70,55 & Berpengaruh \\
\hline & Jumlah & 40 & 21600 & 13304 & 61,59 & Berpengaruh \\
\hline
\end{tabular}

\section{PEMBAHASAN}

Berdasarkan hasil analisis angket yang diberikan pada 135 orang siswa di SMA Negeri 4 Kisaran dapat diketahui bahwa siswa memiliki kesulitan belajar sebesar 61,59\% yang berarti berpengaruh. Persentase masing-masing faktor kesulitan belajar adalah sebagai berikut: indikator kesehatan (41,48\%), indikator perhatian siswa $(65,04 \%)$, indikator intelengensi $(71,01 \%)$, indikator minat $(60,04 \%)$, indikator motivasi $(61,29 \%)$, indikator metode mengajar/strategi mengajar (59,62\%), indikator alat pelajaran $(70,64)$, indikator media $(61,48 \%)$, indikator orangtua $(55,61 \%)$, indikator lingkungan sekolah (70,55\%).

Faktor-faktor yang mempengaruhi kesulitan belajar banyak jenisnya, faktor-faktor yang mempengaruhi proses belajar siswa dibedakan menjadi dua bagian yaitu faktor internal dan faktor eksternal. Berdasarkan analisis angket yang diberikan kepada siswa yang tidak dapat mencapai kriteria ketuntasan maksimum berjumlah 135 orang. Berikut ini akan diuraikan tentang faktor-faktor kesulitan belajar siswa tersebut.

\section{Indikator Kesehatan}

Melalui teknik analisis deskriptif persentase, hasil yang didapat sebesar $41,48 \%$ yang berarti indikator kesehatan termasuk kriteria cukup berpengaruh. Hal ini dapat dilihat masih banyak siswa yang tidak mendengar guru biologi sewaktu mengajar dan siswa mengantuk pada saat kegiatan belajar mengajar dilakukan. Kondisi kesehatan siswa sangat berpengaruh terhadap hasil belajar. Kesehatan fisik anak, jika anak didik tidak sehat badan (sering sakit kepala, demam, dan sebagainya) maka anak didik tidak akan dapat belajar dengan baik, tidak dapat memusatkan perhatiannya untuk belajar. Pendengaran, meliputi kemampuan untuk mendengar suara dengan jelas, kemampuan untuk membedakan nada suara. Penglihatan, kemampuan untuk melihat dengan jelas bacaan dan tulisan dengan berbagai kondisi intensitas cahaya, jarak penglihatan (jauh dan 
dekat), kemampuan membedakan spektrum warna (Ahmadi, 2009).

\section{Indikator Perhatian Siswa}

Melalui teknik analisis deskriptif persentase, hasil yang didapat sebesar 65,04\% yang berarti indikator perhatian siswa termasuk kriteria berpengaruh. Hal ini menunjukkan terdapat kesulitan belajar siswa yang berpengaruh dalam mempelajari biologi. Pada angket ini mengenai pemusatan perhatian dan pemikiran siswa pada mata pelajaran biologi. Untuk dapat menjamin hasil belajar berjalan dengan baik, maka siswa dituntut untuk mempunyai perhatian terhadap pelajaran yang dipelajarinya. Jika siswa tidak fokus terhadap pelajaran tersebut, maka tibullah kebosanan sehingga tidak suka belajar (Slameto, 2011).

\section{Indikator Intelegensi}

Melalui teknik analisis deskriptif persentase yang dilakukan, hasil yang didapat sebesar 71,01\% yang berarti indikator intelegensi termasuk kriteria berpengaruh. Hal ini merupakan salah satu penyebab siswa mengalami kesulitan belajar pada pelajaran biologi.

Intelegensi besar pengaruhnya terhadap kemajuan belajar siswa. Dalam situasi yang sama, siswa mempunyai tingkat intelegesi yang tinggi akan lebih berhasil dari pada siswa yang mempunyai intelegensi yang rendah. Akan tetapi siswa yang mempunyai intelegensi yang tinggi belum tentu berhasil dalam belajarnya. Hal ini disebabkan karena belajar adalah suatu proses yang kompleks dengan faktor yang mempengaruhinya. Aspek intelegensi, memiliki peran pada kemampuan siswa untuk menyerap informasi dan menjadikannya sebagai sumber serta upaya penyelesaiannya (Slameto, 2011).

\section{Indikator Minat}

Melalui teknik analisis deskriptif persentase yang dilakukan, hasil yang didapat sebesar 60,04\% yang berarti indikator minat termasuk kriteria berpengaruh. Dari data tersebut menunjukkan bahwa siswa tersebut tidak ada rasa ketertarikan dalam mempelajari biologi. Hal ini bisa saja terjadi karena kurang diminati siswa karena materi tersebut monoton dan banyaknya bahasa-bahasa ilmiah yang akan dihafal siswa, sehingga siswa menjadi jenuh dan bosan mempelajari materi tersebut. Minat merupakan ketertarikan seseorang terhadap suatu hal. Minat siswa akan timbul apabila menerima rangsangan dari luar yang mendorong siswa untuk tertarik pada suatu bidang yang sifatnya menetap. Siswa yang memiliki minat tinggi dalam suatu materi pembelajaran maka akan merasakan perasaan yang senang apabila siswa tersebut aktif dalam proses pembelajaran yang dilakukan (Hamalik, 2010).

\section{Indikator Motivasi}

Melalui teknik analisis deskriptif persentase, hasil yang didapat sebesar $61,29 \%$ yang berarti indikator motivasi termasuk kriteria berpengaruh. Proses belajar siswa, motivasi belajar sangat diperlukan karena hasil belajar siswa akan meningkat dengan adanya motivasi yang kuat dari dalam diri siswa tersebut. Motivasi dalam diri merupakan hal yang utama untuk mendorong siswa melakukan sesuatu. Jika siswa tidak memiliki motivasi didalam dirinya maka siswa tersebut tidak akan bersemangat dalam mengikuti pelajaran. Kuat atau lemahnya motivasi seseorang turut mempengaruhi keberhasilan dalam belajar. Karena itu, motivasi belajar perlu diusahakan, terutama motivasi yang bersal dari dalam diri karena dengan cara senantiasa memikirkan masa depan yang penuh dengan tantangan dan harus dihadapi untuk mencapai cita-cita yang diingini. Dalam kegiatan belajar, motivasi dapat dikatakan sebagai daya penggerak dalam diri siswa untuk melakukan kegiatan belajar (Djamarah, 2011).

Faktor eksternal adalah faktor yang berasal dari luar diri sendiri. Faktor internal terdiri dari indikator metode/strategi mengajar guru, indikator alat pelajaran, indikator media, indikator orangtua, dan indikator lingkungan sekolah (Slameto, 2011).

\section{Indikator Metode/Stategi Mengajar guru}

Melalui teknik analisis deskriptif persentase yang dilakukan, hasil yang didapat sebesar 59,62\% yang berarti indikator metode/strategi termasuk kriteria cukup berpengaruh. Dari data tersebut menunjukkan bahwa penggunaan metode mengajar kurang bervariasi sehingga membuat siswa menjadi jenuh bahkan menjadi tidak memperhatikan guru sewaktu menerangkan. Metode mengajar guru yang kurang baik akan mempengaruhi belajar siswa. Metode mengajar yang kurang baik itu dapat terjadi misalnya guru yang kurang persiapan dan kurang menguasai materi yang hendak diajarkan sehingga guru tersebut menyajikan materi tidak jelas. Agar siswa dapat belajar dengan baik, maka metode mengajar harus diusahakan semaksimal mungkin (Djamarah, 2011).

Utomo dan Primiani (2009) menyatakan dalam penelitiannya bahwa masih kurangnya kemampuan guru dalam memilih metode dan menggunakan metode sehingga minat dalam belajar berkurang, 
penggunaan metode mengajar hendaklah sesuai dengan materi sehingga dapat melibatkan siswa secara aktif.

Popi (2015) menyatakan dalam penelitiannya bahwa masih kurangnya kemampuan guru dalam memilih metode dan menggunakan metode sehingga minat siswa dalam belajar berkurang, penggunaan metode mengajar hendaknya sesuai dengan materi sehingga dapat melibatkan siswa secara aktif.

\section{Indikator Alat Pelajaran}

Melalui teknik analisis deskriptif persentase yang dilakukan, hasil yang didapat sebesar 70,64\% yang berarti indikator alat pelajaran termasuk kriteria berpengaruh. Alat pelajaran sangat berguna untuk meningkatkan hasil belajar siswa. Dari data yang didapat bahwa alat pelajaran berpengaruh terhadap proses belajar mengajar. Terlihat kurangnya alat dan bahan dalam laboratorium dan kurangnya koleksi buku pada perpustakaan pada saat pelajaran biologi, perpustakaan tersedia tetapi buku-buku yang mengenai biologi tidak begitu lengkap. Menurut Daryanto (2010) mengatakan bahwa alat pelajaran yang lengkap dan tepat akan mempelancar penerimaan bahan pelajaran yang diberikan kepadasiswa. Jika siswa mudah menerima pelajaran dan menguasainya, maka belajar siswa akan menjadi lebih semangat. Sekarang ini banyaknya jumlah siswa yang masuk sekolah, maka memerlukan alat bantu untuk memperlancar belajarsiswa dengan jumlah yang besar seperti perpustakaan, laboratorium serta media-media pembelajaran lainnya. Alat pelajaran yang dimaksud adalah faktor yang dipandang turut menentukan tingkat keberhasilan belajar siswa dan mengusahakan alat pelajaran yang baik dan lengkap agar guru dapat mengajar dengan baik sehingga siswa dapat menerima pelajaran dengan baik.

\section{Indikator Media}

Melalui teknik analisis deskriptif persentase yang dilakukan, hasil yang didapat sebesar $61,48 \%$ yang berarti indikator media termasuk kriteria berpengaruh. Dari hasil penelitian menunjukkan siswa jarang melihat acara TV yang mengenai tentang pelajaran biologi. Guru jarang menggunakan media pelajaran seperti infocus, LCD dan media lainnya untuk membuat siswa menjadi lebih paham dengan materi yang diajarkan. Media pendidikan sebagai salah satu sumber belajar untuk membantu guru memperkaya wawasan siswa. Media yang lebih untuk menunjang tercapainya tujuan pengajaran tentunya akan lebih diperhatikan sedangkan media yang kurang menunjang tercapainya tujuan pengajaran tentunya tidak dipergunakan. Media yang dimaksud adalah penggunaan media ITC untuk menjelaskan materi pelajaran biologi serta fasilitas pendukung dalam mempelajari mata pelajaran biologi (Syah, 2011). Namun, dari hasil penelitian yang dilaksanakan di SMA Negeri 4 Kisaran menunjukkan bahwa indikator media pembelajaran termasuk salah satu faktor yang menyebabkan siswa mengalami kesulitan belajar.

\section{Indikator Orangtua}

Melalui teknik analisis deskriptif persentase yang dilakukan, hasil yang didapat sebesar 55,61\% yang berarti indikator orangtua termasuk kriteria cukup berpengaruh. Peran orangtua sebagai tempat yang utama dan pertama dalam pembinaan dan pengembangan potensi anak-anaknya. Namun tidak semua orangtua mampu melaksanakannya dengan penuh tanggung jawab dikarenakan berbagai alasan seperti kedekatan anak kepada orangtuanya, kurangnya dukungan orangtua kepada anak seperti pembenahan buku-buku yang berkaitan dengan pelajaran biologi, kurangnya kesadaran orangtua terhadap pengaturan waktu belajar anak, dan kurangnya respon orangtua dalam mendampini siswa mengejakan tugas sekolah. Cara orangtua mendidik anak juga sangat lah berpengaruh terhadap hasil belajar anak (Slameto, 2010).

\section{Indikator Lingkungan Sekolah}

Melalui teknik analisis deskriptif persentase yang dilakukan, hasil yang didapat sebesar 70,55\% yang berarti indikator lingkungan sekolah termasuk kriteria berpengaruh. Fasilitas sekolah kurang diterapkan kepada siswa, seperti halnya dengan laboratorium kegiatan ini jarang digunakan pada saat jam pelajaran biologi. Laboratorium yang baik seharusnya dilengkapi dengan berbagai fasilitas yang lengkap untuk mendukung pembelajaran biologi (Djamarah, 2011).

\section{KESIMPULAN}

Dilihat dari hasil penelitian menunjukkan bahwa faktor internal penyebab kesulitan belajar siswa yaitu kesehatan, perhatian siswa, intelegensi, minat, motivasi sedangkan faktor eksternal penyebab kesulitan belajar siswa yaitu metode/strategi mengajar guru, alat pelajaran, media orangtua dan lingkungan sekolah.

Hasil analisis menyatakan penyebab kesulitan belajar siswa dari faktor internal yang paling besar pengaruhnya terdapat pada indikator intelegensi, hal 
ini dikarenakan kurangnya pemahaman siswa untuk memahami konsep-konsep biologi. Sehingga membuat siswa menjadi kurang minat dan termotivasi untuk mempelajari mata pelajaran biologi. Faktor eksternal yang menyebabkan besar pengaruhnya terhadap kesulitan belajar siswa, adalah alat pelajaran yang digunakan siswa dalam mengikuti pelajaran pada saat mata pelajaran biologi. Seperti kurangnya bukubuku biologi untuk menunjang proses pembelajaran dan kurangnya penggunakan media saat kegiatan belajar mengajar berlangsung, sehingga membuat siswa mengalami kesulitan belajar.

\section{UCAPAN TERIMA KASIH}

Terima kasih terkhusus kepada dosen pembimbing, Ahmad Shafwan, S. Pulungan, S.Pd., M.Si yang telah banyak memberikan banyak masukan dan saran hingga terselesaikannya penelitian ini. Dan kepada Ibu Esmi Pohan, M.Pd., selaku Kepala Sekolah SMA Negeri 4 Kisaran, Ibu Arlina Sinaga, S.Si., selaku guru biologi SMA Negeri 4 Kisaran yang bimbingannya selama penelitian berlangsung dan siswa-siswi kelas XI MIA yang telah banyak membantu selama penelitian berlangsung.

\section{DAFTAR PUSTAKA}

Abdurrahman, M., (2009), Pendidikan Bagi Anak Berkesulitan Belajar, Rineka Cipta, Jakarta.

Ahmadi, A., (2009), Psikologi Umum, Rineka Cipta, Jakarta.

Arikunto, S., (2013), Manajemen Penelitian, Rineka Cipta, Jakarta.

Campbell, N,A., Reece, J, B., Mitchell, L, G., (1998), Biologi Edisi Kelima Jilid 1, Erlangga, Jakarta.

Daryanto., (2010), Belajar Mengajar, Rineka Cipta, Jakarta.

Dimyanti., (2013), Belajar dan Pembelajaran, Rineka

Cipta, Jakarta.

Djamarah, S., (2011), Psikologi Belajar, PT. Rineka Cipta, Jakarta.

Hamalik, O., (2010), Kurikulum dan pembelajaran, Bumi Aksara, Jakarta.

Marus, A., (2013), Mengatasi Kesulitan Belajar Melalui Klinik Pembelajaran, Jurnal Edukasi Vol 4, Nomor 2.

Oman, K., (2014), Biologi 1 Kelas X, Grafindo, Jakarta.

Popi, M., Lestari, R., Karno, R., (2015), Analisis Kesulitan Belajar Pada Materi Tumbhan Kelas $X$ Di SMAN Rambah Hilir Tahun Pembelajaran 2014/2015, Jurnal Wahana Inovasi Vol 5, Nomor 2.
Priadi, A., (2017), Biologi 1 Kelas X SMA, Yudistira, Jakarta.

Hidayatussaadah, R., Sukarni, H., Siti, U., (2016), Identifikasi Kesulitan Belajar Siswa Pada Materi Archaebacteria dan Eubacteria Di SMA Negeri 1 Muntilan, Jurnal Pendidikan Vol 5, Nomor 7.

Siti, U., (2010), Analisis kesulitan Belajar Siswa Dalam Memahami Konsep Biologi Pada Konsep Monera, UIN, Jakarta.

Sunarto, H., (2008), Perkembangan Peserta Didik, Rineka Cipta, Jakarta.

Suryati, T., (2007), Biologi 1 SMA Kelas X, Yudistira, Bandung.

Slameto, (2010), Belajar dan Faktor-Faktor yang Mempengaruhinya, Penerbit Reka Cipta, Jakarta.

Sudijono, A., (2010), Pengantar Statistik Pendidikan, Penerbit Rajawali, Jakarta.

Sudjana, N., (2009), Metode Statistik, Penerbit Tarsito, Bandung.

Syah, M., (2010), Psikologi Pendidikan dengan Pendekatan Baru. Penerbit PT. Remaja Rosdaya karya, Bandung. 